\title{
Ovarian Gynandroblastoma
}

National Cancer Institute

\section{Source}

National Cancer Institute. Ovarian Gynandroblastoma. NCI Thesaurus. Code C3072.

A rare neoplasm arising from the ovary. Although it may occur at any age, it is more often seen in young females. Morphologically, it is characterized by a mixture of two cellular populations: well differentiated Sertoli cells and granulosa cells, with the latter constituting at least ten percent of the neoplasm. The vast majority of cases are stage I lesions at presentation and produce either estrogenic or androgenic manifestations. Although it may present as a massive ovarian tumor, it usually follows a benign clinical course. Very rare case reports of testicular lesions morphologically resembling gynandroblastomas are in fact variants of juvenile granulose cell tumor, or Sertoli cell tumor, or a combination of both. 